\begin{tabular}{|c|c|c|c|}
\hline $\begin{array}{c}\text { RESEARCH } \\
\text { ARTICLE }\end{array}$ & $\begin{array}{r}\text { ADVANCE RESEARCF } \\
\text { Volume } 9 \mid \text { Issue } 2 \mid \mathrm{D}\end{array}$ & $\begin{array}{l}\text { OCIAL SCIENCE } \\
\text {-0976-5611 }\end{array}$ & \\
\hline $0=$ & DOI: 10.15740/HAS/ARJSS/9.2/164-169 & Visit us : www.researchjournal.co.in & \\
\hline
\end{tabular}

\title{
A comparative study on living condition and well being of male and female aged residing in selected areas of Western Rajasthan
}

Mridula Bahura* and Kunjan Trivedi

Department of Home Science, Jai Narain Vyas University, Jodhpur (Rajasthan) India

(Email : kalki_kt@yahoo.com; mridulanaveen@gmail.com)

\section{ARTICLE INFO :}

$\begin{array}{lll}\text { Received } & : & 08.08 .2018 \\ \text { Revised } & : & 06.11 .2018 \\ \text { Accepted } & : & 09.11 .2018\end{array}$

\section{KEY WORDS :}

Living condition, Well being, Aged

\section{HOW TO CITE THIS ARTICLE :}

Bahura, Mridula and Trivedi, Kunjan (2018). A comparative study on living condition and well being of male and female aged residing in selected areas of Western Rajasthan. Adv. Res. J. Soc. Sci., 9 (2) : 164-169, DOI: 10.15740/HAS/ ARJSS/9.2/164-169.

Copyright@2018 : Hind Agri -

Horticultural Society

*Author for correspondence

\begin{abstract}
In Indian societies aged are provided a significant position. In traditional India ageing was not at all seen as a problem, in fact traditional norms and values of Indian society laid stress on showing respect and providing care for the aged. The dawn of modernization, industrialization, urbanization, occupational differentiation, education, and growth of individualistic philosophy has windswept the traditional values. These all have huge impact on living condition and well being of aged. Wellbeing is an indicator of one's quality of life, happiness and positive health. Therefore this study was carried out with the objective to assess and compare living condition in addition to well being of aged residing in Western Rajasthan. For this purpose 640, male and female, aged were selected with snowballing method. The result revealed that well being of both male and female aged in Western Rajasthan is enhanced with increase in their living condition being normal.
\end{abstract}

